\title{
Ancient Doctrines of Passions: Plato and Aristotle
}

\author{
Agnieszka Iskra-Paczkowska \\ University of Rzeszow, Poland \\ e-mail: iskra.agnieszka@wp.pl \\ Przemyslaw Paczkowski \\ University of Rzeszow, Poland \\ e-mail: pacz.przem@wp.pl
}

\begin{abstract}
:
The subject of this essay is a discussion of the doctrines of emotions of Plato and Aristotle. According to both them it is impossible to oust the passions from the good, i.e. happy life. On the contrary, emotions are an important component of human excellence. We investigate this question with reference to Plato's doctrine of the soul and his concept of a perfect life, and Aristotle's ethics, poetics and rhetoric.

Keywords: ancient philosophy, passions, ethics, rhetoric, poetics.
\end{abstract}

\section{Foreword}

According to popular opinion, Greek philosophers have evaluated negative emotions as a source of moral evil and a factor increasing the affliction of man [for exaple: 22 - sub voce 'passion' (pathe)]. This, however, is true mainly with regard to the Stoics, who proclaimed the ideal of apatheia-the absolute ousting of emotions from the spiritual life of man. Plato and Aristotle had declared a different view on this issue: not only did they believe that it was impossible to eradicate the passions from the human life, but they also perceived (and analyzed) the role played by emotions in the good (i.e. happy) life. Their ideas are the subject of this article. We will try first to reconstruct the conception of emotions which occurs in the Platonic doctrine of the soul, and then that which is characteristic for Aristotelian ethics, poetics and rhetoric.

\section{Emotions in the Platonic Doctrine of the Soul}

In Plato's dialogue Phaedo (94 d-e) [17] Socrates evokes a passage from The Odyssey (XII, 18-19) [12] describing the inner conflict of Ulysses: "but he smote his breast in self-rebuke, saying: 'Be patient, heart. You stood in grimmer trial"”. 
This Homeric dialogue appears in the Phaedo in the context of the discussion on the nature of the soul and its relation to the body. Lust, anger and fear are treated there as the passions of the body our soul is able to tame, and which we can control when we employ the art of medicine or gymnastics. But in the Republic (441 b-c) [20] the very same passage serves as an illustration of the inner conflict of the soul between its two parts: the rational and irrational [10]. We could say therefore that the doctrine of emotions has evolved in Greek philosophy. But we must emphasize that Greek philosophers have always treated emotions as important categories, without which it is impossible to understand fully the nature of man or explain human activity. Thus the doctrine of emotions has became an important element of ancient psychology, ${ }^{1}$ ethics, the detailed theory of motivation and something that Greeks called psychagoge, and the meaning of which was the art (techne) of acting on the soul (of listener, viewer, reader).

The doctrines of emotions to be found in Plato and Aristotle include many issues also tackled by modern scholars - from the question of the material substrate of consciousness to the analysis of the motivation of human actions. However, these issues were explored from a different perspective than today and the purpose of these studies was different: it is impossible to ignore the metaphysical foundations of ancient psychology, just as we cannot overlook the ethical intention of any ancient theory of action. The psychology of Plato and Aristotle is not the science of the nature of consciousness but of the nature of the soul-its relation to the body and the function it fulfils. Their theories of emotions are a consequence of prior metaphysical settlements, but that means that Plato and Aristotle do answer the question about the material substrate of mental states. Plato, who considered psuche as distinct from the body, ultimately assigned feelings and passions (such as lust, anger, courage) only to the soul, namely to its lower parts: appetite and passion. Whereas Aristotle, who defined the soul as an act of the body, not as a distinct substance, ascribes to the theory that affects can be described in two distinct ways: as an action of the soul or movement of the body. "Dialectically" defined, anger is a lust for revenge, while "materially" —it is ebullition of the blood (De an. 403 a30-b1) [2]. According to Aristotle, metaphysical categories of potentiality and actuality entirely explain the relationship between the material substrate of mental states and their manifestations; that is between the physical and mental events (some authors claim even that he did it in a more sophisticated way than modern theories [11]). To every action of the soul corresponds some physical organ which enables this action, the only exception is the nous, the highest type of mental cognition, who has no physical organ. ${ }^{2}$

The evolution of philosophical views on emotions was closely connected with the debate over intellectualism, which took place in the fourth century B.C. Plato's dialogues Protagoras and The Republic and Aristotle's Nicomachean Ethics were the main stages of this debate. In Protagoras (357e ff.) [19] Socrates argues in favor of the thesis, which ancient Greeks found to be equally paradoxical as modern readers do today, that all human action aimed at some end are: a/ conscious, b/ intended to achieve the good. Desire for the good (good for us equates to happiness) is an irremovable part of our nature, so we do ill unconsciously. The paradox lies in the thesis that all wrong-doings-such as the crimes of the tyrant Archelaus described in Gorgias (471 a-d) [16] do not arise from the desire for the wrong, and the compliance with harmful passions is not a result of weakness of will or immediate lack of self-control, but it results from the intellectual error in appreciation of what is good. Our desires and passions, according to Socrates, always include some conscious component, they are associated with some conviction, and they can be consequently judged as true or false - such is also true of perceptions. In the case of visual illusion I may know that object $\mathrm{A}$ is smaller than $\mathrm{B}$, but because $\mathrm{A}$ is closer to me, I see it as a bigger. What I know and what I see stand in contradiction. Passion-according to the theory presented in Protagora-also includes an opinion on the desired subject, independent of rational knowledge and opened to perspective's misconception: closer pleasure appears as bigger and we have for it a stronger desire, even though we know that it is smaller than other pleasures which are deferred [15].

As we have seen, in Protagoras the yielding to passions (affects, emotions) was interpreted as a cognitive error. In The Republic, in turn, Plato is trying to present an ethical intellectualism in less paradoxical form-as explaining psychical conflicts rather than negating them. The anecdote 
about Leontius (439 b), who feels simultaneously a desire and disgust against the same thing, is a starting point and a premise for the thesis of separate parts of the soul, each of which fosters its own kind of passion. ${ }^{3}$ Akrasia, therefore, is interpreted in the primary sense as a conflict of different desires. This conception of soul does not, however, reject intellectualism, because conflict of desires is ultimately resolved in the intellect. Plato distinguishes the rational and the irrational part of the soul. Desire of the first he calls Eros, ${ }^{4}$ and desire of the other-epithumia (Republic 580d ff.). They differ by their objects: Eros is a love for good, and epithumia is a desire for actual things, unconnected with evaluating them as good. Akrasia is a situation in which a desire (in the instance of Leontius it is his desire to look upon the dead bodies) wins a battle with Eros (a reasonable belief that this view is not good for him). But how is this possible? Only when lust will persuade reason to suffer, that is: to appreciate the object of lust as its own-as the good. Ultimately, akrasia is a cognitive error, a mistake of reason.

It is true that Plato yet distinguished a third part of the soul-thumos, but some scholars say, that the only justification for this step was his intention to be consistent in the analogy between the soul and the state [for example: 15]. Thumos always takes the side of reason in conflict with lust, so it is considered as a rational part of the soul, and its desire (boulesis) - as an element of the characteristics of Eros.

Desires of the soul are certain passions. Plato assumes that there are passions that help a man to achieve the Good and there are the others that prevent him from doing so. Speaking strictly: only with Eros, the passion which had been defined in the Sumposium as a divine element in our soul, can a man achieve the Good; that is, he can realize his true nature. Also, all other passions and desires are not essential obstacles in this task ${ }^{5}$. They can be obstacles only when they succeed in attracting Eros, when, for example, a desire for sensual pleasures or material goods develops into a love of these things. But if Eros does not mistake its proper object (i.e. the Good) with objects of the other desires, these desires can provide access to and be a way to achieve the real Good-Plato describes this way in the Sumposium [21]. One should estimate, therefore, that there is nothing more distant from the Plato's concept of the perfect life than the Stoic ideal of apatheia. A correctly felt passion — the love for the Good (philosophia) — defines the excellence of a man.

\section{Aristotle's Ethics}

In Aristotelian ethics, Plato's conception of emotions has developed into the theory of proper action, founded on psychology and logic. ${ }^{6}$ The practical end of ethics is to form in a man such dispositions and traits of character that enable him to conduct himself in order to attain eudaimonia - a happiness in a sense of success [13]. Right dispositions are virtues, wrong ones are vices. For Aristotle a virtue is a disposition to right acting and being properly affected-praxeis kai pathe - the second word can be understood as feelings, passions and affects (NE Book II) [5]. Pathe comes from paschein, the word which originally meant a misfortune decree of fate. Aristotle mentions as instances of pathe fear, anger, desire, pleasure, pain-however, in the sense of experiencing these feelings. Actions and feelings (poiein - paschein; in general: doing and being done, Categories $9.11 \mathrm{~b} 1 \mathrm{ff}$ ) [1] are different modes of human existence, in the same sense they are different modes of the Being or of the pronouncement of the Being. So ethics is a practical science of how to act properly and how to feel properly, and because feelings are a domain in which there can be an "excess", a "deficiency", and the "right measure", the practical end of ethics is to train a habit for proper emotional responses. Ethics eventually turns out to be a sentimental education, and this remained its characteristic until the end of antiquity [14].

Moral virtue is a proper emotional response to external circumstances. The virtuous man has control over the irrational part of his soul—over his anger, fear, love, lust, jealousy, ambition, envy, hatred, pity, i.e. he feels emotions in the right way and for the right reasons. It is not an incidental control over them, or restraint which comes from the ability that Socrates had called enkrateia, but it is a habit of proper response, backed up by lengthy training. In the purely external, i.e. behavioral, aspect, there is, to be sure, no difference between a self-controlled man and virtuous one-both 
have the ability to proper action. But only a virtuous man has the ability to proper feeling and only he can derive pleasure from good activities ( NE 1104 b23) [24]. Hence, virtuous man is not one who acts good, but someone whose proper conduct is the result of his good character [14]. Virtuous man is distinguished by the lack of that internal conflict between the rational and the irrational part of the soul, which was mentioned at the beginning of this article. His choices are characterized by consistency in the aim for good and they are not accompanied by a suppressed desire for something different. $^{7}$ The self-controlled man, on the other hand, though he also makes good choices, must conquer a desire of the lustful part of his soul. The relationship between desires and rational choices, and the pleasure choices give, are the premise for the classification of states of character in the Nicomachean Ethics : (1) heroic excellence; (2) ordinary excellence; (3) enkrateia; (4) akrasia; (5) badness of character; (6) brutishness (NE 7.1) [24].

The state of character is nothing else than the way in which we experience emotions. The vice (5) is a condition in which emotions are felt improperly-too much or too little. Vice is pushing us to wrong actions, but it is not accompanied by a consciousness of evil or by compunction. Akrasia, a moral weakness (4), is less bad than the vice, because the vehement man, feeling wrong emotions and acting badly, knows he is not acting properly, and suffers as a consequence. Enkrateia (3) is the condition of the soul in which one can act properly in spite of all his improperly felt emotions - the rational part of his soul controls the irrational. Virtue (2), as the opposite of the vice, means the proper feeling of emotions, and good choices, accompanied by pleasure. There are also, according to Aristotle, the extreme states: the highest excellence (1), God's likeness (NE 1145 a15; Pol. 1284 a3 [6]), and the worst defect (6), which makes the human an animal.

Many times in this text we have invoked the Aristotelian phrase "properly felt emotions" and we have asserted that, according to Aristotle, ethics teaches the proper feeling of emotions. What does this mean? Aristotle believes that virtue, the excellence of the soul, is an internal disposition to feel emotions in the right way-neither too much, nor too little. "Too much" ought to be understood as "too often", "too violently", "in inappropriate situations", etc. Because there are a great range of emotions (fear, anger, pity, envy, lust, etc.), and for each there are a state of "excess", "deficiency", and "right measure", there are also many different virtues and-at least-twice as many vices (in respect of each emotion - one defect is "too much" of this emotion, the other is "not enough"). It seems at the same time (although some statements of Aristotle apparently contradict this), ${ }^{8}$ that there are no emotions one should not feel in any way, that is, for which there is no right measure [24]. In his statement of the multitude of virtues, however, Aristotle has not diverted far from the views of Socrates and Plato (who proclaim the unity of virtues), because he believed that a man who has a virtue to the full degree (understanding virtue as supported by phronesis), also has all the others (NE 1110 b18).

Because there is only one right measure in the affections, and wrong are many, it is extremely difficult to be a virtuous man; it is possible to be a defective man in many ways, a good man-only in one (NE $1106 \mathrm{~b} 29$ ). We ought to point out, however, that the right measure is not a practical guide for moral conduct in specific situations, it has also nothing to do with the mean in the purely mathematical sense. The right measure defines a virtue: virtue is a disposition (hexis) to refer to the passions properly. Properly to the person, not to the object: there is, for example, no proper measure in eating cheese (cheese was, in ancient Greece, the primary component of the diet of the Olympians), there is, in contrast, the proper measure for each particular player (NE $1106 \mathrm{~b} 1)$. And in his case this measure is the same as the virtue of temperance. Let us summarize: virtue means the ability to feel passions (a fear, courage, desire, anger, pity, etc.) at the right time, for the right reasons, to the right people, for the right end, and in the right way (NE $1106 \mathrm{~b} 18$ ).

Moral excellence, as well as moral weakness, according to Aristotle, lies within our power ( $N E 1113 \mathrm{~b} 4)$; we are responsible for what men we are. In particular, we are responsible for the way in which we experience emotions, feelings and desires. It sounds paradoxical: being affected is not, after all, a matter of our free choice, Aristotle himself says that emotions are apohairetic-if something angers us, worries us, or arouses our desire or love, it happens to us without our will 
(Catt. 9 a23; Met. 1046 a13 [4]). We can, however, develop the habit of proper experience of emotions, the habit of the emotional response to different circumstances, which is neither too sharp, nor too sluggish. The proper response to a danger is to protect our health or life, or that of the people whom the danger threatens. It is the result of some fear for the preservation of the most important goods in this situation. This properly felt fear is courage, an emotional response of the soul, leading to good actions (sometimes we put our own life at risk-when it derives from worrying about the loss of the greater good).

This can be learnt, says Aristotle. The virtues are hexeis - this means that they are neither natural (innate), nor something opposite to the nature. They are habits that we can develop through the process which Aristotle calls ethismos (a custom): we become brave by doing brave actions ( $N E$ 1103 a28). ${ }^{9}$ Because our actions are definitely a matter of choice, ultimately so too is virtue - not in a simple way, but by the actions we choose [14]. We choose actions; these form our habits; habits form our character; and a formed character means proper feeling of emotions. Moral (scil. emotional) education has, according to Aristotle, a great deal in common with training in the arts (technai). Children, based on the example set by wise adults, repeat some virtuous actions, for example, daring deeds. It is not yet the courage, just as practicing is not the same as the ability to play a musical instrument. The child is not able to judge what is appropriate in a given situationhe knows this only from adults. However, in course of time, experience creates in us a more general knowledge (although not the same as in the theoretical sciences) about the requirements which virtue (for example the virtue of courage) puts before us in similar circumstances. Moral education leads us to establish the habit of feeling a given emotion in the way which a given occasion demands: e.g. avoiding anger when it is appropriate, and feeling it when it is appropriate. This conception was a standpoint which Aristotle took in a long dispute between poets, tragedians, sophists and philosophers about the source of virtue: from nature, habit or teaching [23].

\section{Poetics}

Aristotle's doctrine of emotions has also its expression with reference to the arts based on the use of words-poetics and rhetoric. They are united by the same end, i.e. arousing pity, fear, anger and other feelings in the soul of the viewer or listener. The only difference is the need to explain the position which is characteristic of rhetoric and needless in tragedy.

In terms of tragedy, it contributes to the refinement of emotions, to "spiritual efficiency", to finding pleasure in right things. Interestingly, however, the principle of right measure does not apply to the experience of the aesthetic: the pleasure by which the experience of beauty is accompanied, even if it occurs in excess, does not make a man licentious, as its deficiency does not make a man frigid ( $N E 1117 \mathrm{~b} 30 ; E E 1230 \mathrm{~b} 31$ [3]). It is the only affection in case of which the lack of measure does not equate to a defect in character.

Poetry (and mimetic arts in general) forms our habits, it is able to make our life moral and satisfactory, and thus it is able to give us happiness (Cf. Pol. 1339 b18). Unlike Plato, Aristotle does not discern the "negative charm" of poetry. This difference between Plato and Aristotle can be seen apparently when we confront their ideas about happiness. According to Plato, poetic imitation enhances those habits which should be limited-instead of becoming better and happier, we become worse and less happy (Republic 607a). But according to Aristotle poetry gives us real pleasure and entertainment, and it causes some spiritual purification. It contributes to our happiness - the feeling of happiness consists in fact of beauty and delight (Pol. 1339 b20). Aristotle's definition of tragedy specifies its end-accomplishing by way of the evoking of pity and fear the catharsis of such feelings (Poet. 1449 b27) [7]. It is difficult to say whether katharsis relies on purging of feelings, or purification of feelings [9], in any case, the viewer should achieve through it an inner harmony.

In the structure of tragedy the most important thing is the story or plot, and there are two elements through which it most strongly influences the feelings of the recipient: the reverse of fate (perypeteia) and the recognition (anagnorisis, Poet. 1450 a33). Another important element of the plot is pathos - a painful, irreversible and fatal incident (1452 b10). For arousing the viewer's 
emotions the construction known as muthos is necessary, so that viewer could believe. The poet should therefore present such incidents that are feasible, based on probability or necessity (Poet. 1451 a38), but also that are able to evoke pity and fear. This effect can be better achieved the more inconsistent are events with the expectations of the audience, yet still retaining the element of feasibility. The surprise effect is significant-it decreases when events are ruled by the coincidental or when they occur spontaneously, and increases when events give the impression of being intended (Poet. 1452 a4). The two components of the story-perypeteia and anagnorisis-should logically result from events for the proper emotional effect. Aristotle examines the different types of plot and their impact on the feelings of the audience. Feelings associated with watching the tragedy can be aroused in two ways: by "stage setting" or by the incidents only. The second way is evidence of greater poetic craftsmanship and it is of a higher quality, it lets us to feel pity and fear by contact with the text, there is no need to watch a performance in the theater. It is important because the "stage settings" can wake up feelings with no connection to the tragedy, dismay for example. And in the tragedy we ought to look only for those pleasures which are proper for it (Poet. 1453 b10).

The second element of tragedy on which the emotional response of audience depends is the construction of the hero. He should not be spotless ("pre-eminently virtuous and just") because his defeat would cause an outrage rather than pity and fear. He should also not be depraved because his fall could give pleasure. The emotional tie (pity) with the tragic hero is a result of the undeserved misfortune of an innocent man, someone whose defeat is the result of a "great mistake" (hamartia), and not of moral fault. The fear, in contrast, derives from the misfortune of a man who is like us (Poet. 1453 a4). The drama of the hero is best rendered by a poet when he is able to convey the emotions of the hero, and to set the audience in an emotional state that corresponds to the tragic situation. A close relationship between the protagonists is the norm for the tragedy, especially in the case when the offender is not aware of his kinship with the victim (like Oedipus)—anagnorisis gives the audience a shocking impression (Poet. 1453 a3). But the case arousing the strongest emotions is the situation in which the hero recognizes his victim just before committing a deed and this prevents him from taking action (like Meropa or Ifigenia; Poet. 1454 a5). For the creation of an emotional tie with the hero his character is also important: nobility, a similarity to human behaviour in general (this gives common ground with the audience), a consistency (even an inconsistent hero must be consistent in his inconsistency; Poet. 1454 a16).

\section{Rhetoric}

Now, let us move on to rhetoric. Rhetoric is a practical skill and, at the same time, a large system of rules and methods to guarantee success in the field of persuasion through words. The rhetorical argumentation cannot adhere to the formal discipline of sciences, because its conditions are not certain but probable. Indeed, Aristotle himself criticizes those authors who analyze the strategies of emotional influence on the listeners, but in Book II of Rhetoric [8] he discusses in details the methods of arousing feelings. In the ideal situation, when a rational rhetor speaks to rational listeners, emotional influence is not needed. In social practice, however, even an expert is not able to convince the entire audience, especially those who lack competence in logical argumentation. In this case, the arguments need to be based on the common experience (Rhet. 1355 a25). Since the aim of rhetoric is practical, it is necessary to adapt a strategy to the realities of political life. There are three ways to impact on the listeners: by evoking ethical resonance, emotional resonance, or by rational arguments (Rhet. 1356 a1). We are most interested in this second. The speech has to act on the emotions of the listeners (it has to move), the rhetor should have knowledge of human characters and the ability to analyze emotions: to identify the nature of each emotion, its properties, sources, and the way it can be aroused (Rhet. 1356 a20). In other words, he should have the knowledge necessary to determine what is convincing for a particular type of men (what is good for them). In the Rhetoric Aristotle analysis the emotions man can feel: anger, contempt, disregard, gentleness, fear, courage, sympathy, friendship, hatred, hostility, shame, shamelessness, kindness, pity, indignation, envy, and ambition. He draws a map of human emotions: some of them he assigns 
to a noble man (ambition), others to someone ignoble (envy), some of them he considers as typical for young people (passions), the other for the mature (distrust and suspicion).

\section{Conclusion}

The philosophy of the ensuing era was dominated by stoicism, which proclaimed a radically different idea: that our emotions are the only cause of human disease. And if it would be a certain exaggeration to say that stoicism has became the lay religion of the aristocratic Roman society, then it would be no exaggeration to say that it became one of the most important elements of education and moulded the mentality of the era. As we have emphasized, the Stoics proclaimed ideal of apatheia. However, at the same time they were writing the treaties whose practical aim was to teach the proper emotional attitude in different situations and circumstances, such as: About anger, About love to children, About happiness, About cheerfulness, About brotherly love, About loquacity, About snooping, About the lust for wealth, About false shame, About envy and hatred. It can be said, therefore, that stoicism in the Roman era proclaimed two ethics: a theoretical one referring to the Socratic ideal of the sage, and practical one which was in fact the legacy of Aristotle and his doctrine of how to be properly affected. The first declared an unobtainable ideal, in which passion should be completely ousted from spiritual life; the other spoke to the common man and taught him how to form character by practicing the control of passions such as desire or fear, and by competent directing of affects such as anger.

\section{References}

1. Aristotle. Categories. In. W. D. Ross, J. A Smith (eds.). The Works of Aristotle tr. into English. Oxford and the Clarendor Press, 1912.

2. Aristotle. De Anima. In. W. D. Ross, J. A Smith (eds.). op. cit.

3. Aristotle. Eudemian Ethics. In. W. D. Ross, J. A Smith (eds.). op. cit.

4. Aristotle. Metaphysics. In. W. D. Ross, J. A Smith (eds.). op. cit.

5. Aristotle. Nicomachean Ethics. In. W. D. Ross, J. A Smith (eds.). op. cit.

6. Aristotle. Politics. In. W. D. Ross, J. A Smith (eds.). op. cit.

7. Aristotle. Poetics. In. W. D. Ross, J. A Smith (eds.). op. cit.

8. Aristotle. Rhetoric. In. W. D. Ross, J. A Smith (eds.). op. cit.

9. Barnes, J. Rhetoric and Poetics. In. J. Barnes (ed.). The Cambridge Companion to Aristotle. Cambridge University Press: Cambridge, New York, 1995, pp. 259-286.

10. Dodds, E. R. Plato and the Irrational Soul. In. G. Vlastos (ed.). Plato. The Collection of Critical Essays. Vol. II: Ethics, Politics, and Philosophy of Art and Religion. Anchor Books: New York, 1971, pp. 206-229.

11. Everson, S. Psychology. In. J. Barnes (ed.). op. cit., pp. 168-194.

12. Homer. The Odyssey. Transl. by T. E. Lawrence. Wordsworth Editions Limited: Ware, 1992.

13. Hucthinson, D. C. Ethics. In. J. Barnes (ed.). op. cit., pp. 195-232.

14. Kosman, L. A. Being Properly Affected: Virtues and Feelings in Aristotle's Ethics. In. A. O. Rorty (ed.). Essays on Aristotle's Ethics. University of California Press: Berkeley and Los Angeles, 1980, pp. 103-116.

15. Penner, T. Thought and Desire in Plato. In. G. Vlastos (ed.). op. cit., pp. 96-118.

16. Plato. Gorgias. In. I. Burnet (rec.). Platonis opera. Oxoni 1955-7.

17. Plato. Phaedo. In. I. Burnet (rec.). op. cit.

18. Plato. Phaedrus. In. I. Burnet (rec.). op. cit.

19. Plato. Protagoras. In. I. Burnet (rec.). op. cit.

20. Plato. Republic. In. I. Burnet (rec.). op. cit.

21. Plato. Sumposium. In. I. Burnet (rec.). op. cit. 
22. Reale, G. Historia filozofii starożytnej. Vol. 5. Transl. by E. I. Zieliński, Wydawnictwo Naukowe KUL: Lublin, 2002.

23. Sorabji, R. Aristotle on the Role of Intellect in Virtue. In. A. O. Rorty (ed.). op. cit., pp. 201220.

24. Urmson, J. O. Aristotle's Doctrine of the Mean. In. A. O. Rorty (ed.). op. cit., pp. 157-170.

Notes

1. In some sense, the term "psychology" is anachronistic with reference to ancient philosophy, meaning in fact rather the doctrine of the soul.

2. A possible conclusion of this thesis is the immortality of the nous. Aristotle, however, does not deal with this issue.

3. Leontius wishes to see the bodies of killed prisoners, but he is also afraid of this nasty view. Eventually he yields the temptation but condemns himself for this.

4. But not in the traditional sense of the word, rather in the original metaphysical sense which he has presented in the Sumposium, where philosophy is presented as 'erosophia'.

5. Due to the limited framework of this article we do not discuss extremely important concept of mania. Plato writes about it in the first place in the Phaedrus [18].

6. Example of which is the theory of the practical syllogism.

7. It is probably something significant for the era in which Seneca and St. Paul were living, that they both saw this attitude as an ideal unattainable for earthly man-you have to be a sage or enjoy the grace of God to cope with it.

8. NE 1107 a9. The passions which Aristotle enumerates-the joy of failure of other people, shamelessness, and envy-are rather extreme states of other emotions. Hence Aristotle's sugegestion: there is no right measure in excess or deficiency (1107 a 25-6).

9. Hence the title Ethike for Aristotle works. 